\title{
MISÉRIA DA FILOSOFIA: NO EMBATE ENTRE MARX E PROUDHON, OS ELEMENTOS DO MÉTODO MARXIANO
}

\author{
Vilson Aparecido da Mata ${ }^{1}$
}

\begin{abstract}
Resumo: O texto aqui apresentado resulta de estudos elaborados sobre a obra Miséria da Filosofia, reconhecendo no texto marxiano de 1847 os primeiros elementos do método materialista histórico e dialético. O objetivo é ressaltar que, em Marx, o método dialético materialista não pode ser dissociado de uma perspectiva mais ampla de transformação social radical. Isso fica exposto no fato de que, em sua crítica a Proudhon, Marx desconstrói por completo a perspectiva reformista do socialismo, opondo a ela uma abordagem que encaminha a transformação profunda da sociedade como única alternativa à superação das contradições existentes no capitalismo. A obra é uma contribuição importante para a análise das perspectivas reformistas, bem como para a melhor compreensão da naturalização das relações sociais burguesas. Quando não aceita a polarização entre os lados bom e mal da sociedade, o filósofo alemão indica o entendimento de que as mesmas relações sociais que criam a riqueza criam, também, a pobreza daqueles que produzem. A riqueza é puramente uma riqueza burguesa e não uma riqueza social. O método marxiano tem, no texto aqui analisado, seus princípios delineados, princípios que, aliás, permanecerão vívidos e presentes por toda obra marxiana.
\end{abstract}

Palavras-Chave: Materialismo Histórico e Dialético. Marx. Socialismo. Revolução. Emancipação.

\begin{abstract}
The current text is the result of studies produced on the work The Poverty of Philosophy, recognizing in the Marxist text from 1847 the first elements of the historical and dialectical materialistic method. The objective of this work is to highlight that, in Marx, the materialistic dialectical method cannot be dissociated in a broader perspective of a radical social transformation. It becomes evident through the fact that, in its criticism towards Proudhon, Marx deconstructs completely the reformist perspective of socialism, opposing it an approach that routes to the deep transformation of society as the only alternative to the overcoming of the existent contradictions in capitalism. The work is an important contribution to the analysis of the reformist perspectives, as well as to understand better the naturalization of the bourgeoisie social relations. When the polarization between good and bad sides of society is not accepted, the German philosopher points the belief that the same social relations that create wealth also create the poverty of those who produce it. Wealth is purely a bourgeoisie wealth and not a social one. In the text analyzed here, Marxist method's principles are outlined, principles which, in fact, will remain vivid and present throughout all the Marxist work.
\end{abstract}

Keywords: Dialectical and Historical Materialism. Marx. Socialism. Revolution. Emancipation.

\footnotetext{
${ }^{1}$ Graduado em Educação Física pela Universidade Estadual de Maringá (1991), mestre em Educação pela Universidade Estadual de Maringá - área de concentração em Fundamentos da Educação (2000) e doutor em Educação pela Universidade Federal do Ceará - área de concentração em Filosofia e Sociologia da Educação (2014). Atualmente é professor da Universidade Federal do Paraná (UFPR). Tem experiência na área de História e filosofia da Educação, com ênfase em Fundamentos da Educação e Fundamentos da Educação Física, atuando principalmente nos seguintes temas: Filosofia da Educação, Corpo e Filosofia, Fundamentos Históricos e Filosóficos da Educação e Filosofia Política e Educação.
} 


\section{Introdução}

A Miséria da Filosofia, publicada em 1847, não é a obra mais conhecida, tampouco a mais analisada de Marx. Escrita ainda em 1846 é um texto inaugural do pensamento marxiano em dois aspectos: primeiro, Marx utiliza, pela primeira vez, o modo de análise da sociedade que completou, junto com Engels, em a Ideologia Alemã. Segundo, é o primeiro texto sobre economia política efetivamente publicado por Marx (os Manuscritos Econômico-Filosóficos e os Cadernos de Paris só ganharam publicação no século XX).

Em A Miséria da Filosofia, Marx enfrenta Proudhon, destacado pensador ligado à pequena burguesia francesa cujos escritos exerceram forte influência sobre o operariado daquele país, sendo considerado um dos fundadores do anarquismo. Em que pese o fato de que Proudhon já fosse um pensador reconhecido quando da chegada de Marx à Paris e que, em seu primeiro contato com ele, Marx tenha se inclinado a tê-lo como aliado e interlocutor, as divergências a respeito dos caminhos a serem trilhados pelo operariado definiram uma ruptura definitiva entre esses pensadores, ao ponto de assinalar duas perspectivas divergentes no interior do próprio socialismo. Para Netto, o enfrentamento entre Marx e Proudhon "assinala tanto a diferenciação políticoideológica (sic), crucial e qualitativa, entre duas perspectivas socialistas - a reformista e a revolucionária -, quanto, simultaneamente, o embasamento da teoria social moderna" (NETTO, 2009, p. 11).

São essas divergências que constituem o escopo do texto de Marx. O livro de Proudhon, Sistema das Contradições Econômicas ou Filosofia da Miséria, apresenta como solução para as desigualdades sociais presentes no capitalismo um caminho reformista, de manutenção daquilo que o capital produziu de positivo, eliminando aquilo que se constituiu como negativo. Para Marx, tal empreendimento é irrealizável por não ser possível reformar o capital, posto que suas contradições sejam imanentes. Não se elimina aquilo que desumaniza mantendo o que humaniza, pois o modo de produção capitalista é desumanizante em essência.

Há ainda reflexões e apontamentos que o filósofo alemão reformula desde os textos iniciais, de 1843-44 e outros que se estenderão até a maturidade. O embate com Proudhon constitui um momento de suma importância para o método marxiano, que é posto à prova na análise da obra do pensador francês. Aparentemente, a reforma do capital se apresenta como fenômeno possível uma vez que as desigualdades sociais são

\begin{tabular}{|l|l|l|l|l|}
\hline Govista Dialectus & Ano 3 & n. 8 & Janeiro - Agosto 2016 & p. 77-93 \\
\hline
\end{tabular}


gritantes. Entretanto, aquilo que é fenomenicamente evidente esconde uma essência que não pode ser reformada. Por um lado, parece que a superação dos defeitos decorrentes do capitalismo encaminha a possibilidade de se aproveitar aquilo que de melhor se produziu nessa forma organizativa da produção humana; por outro, as próprias bases sobre as quais essa mesma produção se assenta impossibilitam a reforma, pois são elas que criam as desigualdades presentes.

À primeira vista, o texto de Proudhon se mostra como um postulado da classe trabalhadora. Porém, quando desnudado pela análise de Marx, esse postulado revela-se reformista, pois não só não contribui para a superação das desigualdades sociais, como as obsta ao considerar que a manutenção do capital sem seus defeitos pode ser o caminho para aquilo que Proudhon considera a verdadeira igualdade de condições, mas que se efetiva como a derrota final das perspectivas de transformação profunda da sociedade.

Trata-se, aqui, de uma concepção polarizada e rígida das contradições presentes na sociedade capitalista. O entendimento é de que haja dois polos, fixos, imutáveis e que se anulam um ao outro: o "lado bom" e o "lado mal" da sociedade. Os polos são capazes de anular, como matéria e antimatéria, e, em Proudhon a questão fundamental é encontrar as categorias que anulam o lado mal da sociedade, colocando-as para trabalhar na manutenção do lado bom.

A contribuição que aqui se apresenta procura expor e refletir sobre os elementos do método marxiano presentes na crítica do filósofo alemão ao livro de Proudhon. Para tanto, é principalmente a partir da segunda parte de A Miséria da Filosofia que se encaminha a análise. Nessa segunda parte, Marx apresenta as principais ideias de Proudhon, analisando-as e contrapondo-se a elas, criticando seus limites e, no mesmo movimento, expondo os princípios fundamentais do método marxiano. Assim, o primeiro momento do texto trata das sete observações feitas por Marx a respeito da obra de Proudhon, particularmente sobre a apreensão defeituosa da dialética hegeliana; a segunda parte trata daquilo que resulta da perspectiva proudhoniana: o lado mau da sociedade capitalista é a classe trabalhadora, porque é a classe trabalhadora que apresenta todos os elementos de desestabilização da sociedade e, por fim, o texto termina apresentando algumas considerações sobre os dois erros de Proudhon e refletindo sobre o papel do lado "mau" da sociedade capitalista.

\begin{tabular}{|l|l|l|l|l|}
\hline Q Povista Dialectus & Ano 3 & n. 8 & Janeiro - Agosto 2016 & p. 77-93 \\
\hline
\end{tabular}




\section{A dialética de Proudhon e a crítica de Marx}

No capítulo sobre a Metafísica da Economia Política, Marx aponta os problemas do método utilizado por Proudhon em sua análise das condições da sociedade em seu tempo. Utilizando-se da economia política inglesa e da filosofia hegeliana, particularmente a interpretação da vertente chamada de esquerda hegeliana, a partir de seus contatos com Karl Grünn e Mikail Bakunin (Cf. MOREL, 2003, pp. 10-13), é que Proudhon pretende aplicar a sua dialética serial aos problemas da economia política. Marx, no entanto, constata problemas no modo como o pensador francês expõe essa dialética serial, bem como no modo como ele apreende a dialética hegeliana, apresentando tais problemas em sete observações.

Na primeira observação, Marx aponta que Proudhon, na verdade, não entendeu a dialética de Hegel, pois toma seus polos como elementos fixos, imutáveis, ou, nas palavras do pensador francês, como categorias lógicas. O movimento do pensamento, então, seria de tudo reduzir a uma categoria lógica, a uma abstração pura. Marx opõe-se a essa formulação, antes de tudo, porque não corresponde à dialética hegeliana, mas a engessa, a torna imóvel, desfigurando-a.

É do entendimento da dialética hegeliana como sendo composta por polos fixos que deriva a dialética serial, criada por Proudhon e que não corresponde ao desenvolvimento histórico do método dialético. O movimento da razão pura, da metafísica, só é possível a partir do domínio da dialética hegeliana e não como oposição entre polos fixos. Neste caso, a razão pura se torna dogma e a metafísica deixa de reconhecer as ilimitadas determinações do pensamento, a história torna-se a ideia que se tem da história. A consequência de tal apreensão equivocada do movimento do pensamento será a polarização das categorias da economia política ${ }^{2}$.

Na segunda observação Marx afirma que, na concepção filosófica (idealista e invertida), as categorias econômicas são expressões teóricas, abstrações das relações sociais. Para Proudhon, as relações de produção são encarnações das categorias econômicas, porém, o pensador francês não observa que as relações sociais também são produzidas pelos indivíduos, assim como as relações de produção. A transformação das

\footnotetext{
${ }^{2}$ Nos Manuscritos econômico-filosóficos (2010) e em A sagrada família (2009, cf. pp. 72-5), Marx expõe o método dialético hegeliano, com pormenores. Levando em conta que são textos anteriores à Miséria da filosofia, podemos supor que o filósofo alemão já dominava as complexidades do método hegeliano com muita propriedade ao empreender a crítica a Proudhon.
}

\begin{tabular}{|l|l|l|l|l|}
\hline Qovista Qialectus & Ano 3 & n. 8 & Janeiro - Agosto 2016 & p. 77-93 \\
\hline
\end{tabular}


relações sociais transforma também as forças produtivas, tornando as ideias tão pouco eternas quanto as relações de produção que exprimem. Nas palavras de Marx:

As relações sociais estão intimamente ligadas às forças produtivas. Adquirindo novas forças produtivas, os homens transformam o seu modo de produção e, ao transformá-lo, alterando a maneira de ganhar sua vida, eles transformam todas as suas relações sociais (MARX, 2009, p. 125).

Os princípios do método marxiano apresentam-se nesta observação sem rodeios: a teoria é a reconstrução do real pelo cérebro, pelo pensamento. A abstração, neste caso, ganha uma base material firme. Proudhon inverte esse entendimento, vendo na realidade somente a encarnação da categoria. A partir daí, chega à compreensão também deformada das relações sociais, desconsiderando que elas mesmas sejam produções humanas. Proudhon se deixa enganar pelo fenômeno, e, por isso, não chega de fato à essência que esse fenômeno expressa.

Os indivíduos não produzem socialmente somente os produtos que satisfazem suas carências, mas também relações sociais cujas bases materiais são as forças produtivas. Juntamente com Engels, Marx havia descoberto que a riqueza espiritual dos indivíduos depende da riqueza de suas relações sociais já na Ideologia Alemã:

Somente assim os indivíduos singulares são libertados das diversas limitações nacionais e locais, são postos em contato prático com a produção (incluindo a produção espiritual) do mundo inteiro e em condições de adquirir a capacidade de fruição dessa multifacetada produção de toda a terra (criações dos homens). (MARX e ENGELS, 2013, p. 41).

Portanto, a riqueza espiritual dos indivíduos não pode ser efetiva se as relações sociais forem limitadas. Esse entendimento, elaborado já no texto de 1845-46, conclui que é na superação das forças produtivas que limitam o desenvolvimento da produção espiritual humana que se torna possível a fruição multifacetada daquilo que a humanidade desenvolveu em suas relações sociais. Por relações sociais, entendemos relações sociais de produção. A base social da produção humana é que constitui, desde os mais primitivos utensílios produzidos pelos humanos até as mais elevadas produções culturais, o modo pelo qual os indivíduos singulares se apropriam das riquezas espirituais. O mundo social é uma produção histórica humana e a forma assumida por

\begin{tabular}{|l|l|l|l|l|}
\hline Qovista Dialectus & Ano 3 & n. 8 & Janeiro - Agosto 2016 & p. 77-93 \\
\hline
\end{tabular}


ele constitui o modo de produção no interior do qual se encontram todas as relações sociais: "o moinho movido pelo braço humano nos dá a sociedade com o susserano; o moinho a vapor dá-nos a sociedade com o capitalista industrial” (MARX, 2009, p. 125).

$\mathrm{Na}$ terceira observação, Marx aponta ainda que as relações de produção de qualquer sociedade constituem um todo, não podem ser apresentadas em sequência linear ou consideradas isoladamente, pois, para se pensar em uma delas, é preciso recorrer a todas elas. Para Marx, as relações de produção coexistem simultaneamente. Isso é oposto ao que afirma Proudhon, para quem as relações econômicas são formadas "por umas tantas fases sociais que se engendram umas às outras, que resultam umas das outras assim como a antítese resulta da tese e que realizam, na sua sucessão lógica, a razão impessoal da humanidade" (MARX, 2009, p. 126).

Em Proudhon, as relações de produção constituem um todo, mas um todo cujas partes dão origem umas às outras, em sequência. Para explicar cada uma das fases, precisa recorrer às demais, que nem sempre estão na sequência que preconiza. A parte, para o pensador francês, explica o todo, o particular define o universal. Para Marx, evidencia-se o erro de tomar o todo pelas partes, de explicar o todo como uma sucessão lógica de suas partes. Marx explica ainda que a realidade deve ser tratada em sua totalidade, as partes, por si só, não explicam a realidade, pois esta não pode ser retirada do todo, embora sejam constituintes da totalidade, esta é maior e mais complexa que a soma de suas partes.

É verdadeiro que a parte também diz o que é o real, também expressa o todo, porém, sozinha, não o explica. O fenômeno só pode ser fenômeno porque expressa a essência, porém, expressar a essência é algo bem diferente de explicá-la. Por outro lado, totalidade não é uma categoria que deva ser entendida como "conhecer tudo", mas como a consideração do objeto no interior de múltiplas determinações. Tomar o todo pela parte não é somente um erro metodológico, no contexto da dialética serial de Proudhon, leva inevitavelmente a um beco sem saída.

A quarta observação ainda trata da descaracterização que Proudhon opera na dialética hegeliana, porém, agora, analisando sua aplicação à economia política. Como, para Proudhon, os polos dialéticos são fixos, imóveis, tornam-se os lados "bom" e "mal" das categorias econômicas, tratadas como partes explicativas da totalidade econômica. Todas as categorias econômicas, portanto, trazem em si essa falsa ambiguidade, que, ao ser apresentada como a existência de polos fixos, torna-se

\begin{tabular}{|l|l|l|l|l|}
\hline Govista Dialectus & Ano 3 & n. 8 & Janeiro - Agosto 2016 & p. 77-93 \\
\hline
\end{tabular}


dogmática. O exemplo dado por Marx é cabal e expõe toda limitação da análise de Proudhon: a escravidão seria uma categoria econômica e, portanto, possui dois lados. Deve-se, então, proceder analisando o lado bom da escravidão, desconsiderando seu lado mau. Porém, qual seria o lado bom dessa obscenidade? "O movimento dialético, para ele, é a distinção dogmática entre o bom e o mau” (MARX, 2009, p. 128).

Marx explica que o movimento dialético é a coexistência de polos contraditórios, que lutam entre si e fundem-se em uma nova categoria. Porém, em Proudhon, não é a categoria que se põe e se opõe a si mesma: "é o sr. Proudhon, que se move, se debate e se agita entre os dois lados da categoria” (MARX, 2009, p. 129). Ou seja, Marx identifica no pensador francês não é o movimento do pensamento que busca a essência da realidade, mas uma subjetividade que, a partir daquilo que identifica, pessoalmente, como sendo os lados bom ou mau de uma determinada categoria, busca imediatamente encontrar-lhe um antídoto que anule o lado mau. A isso Proudhon chama de série no entendimento.

Segundo essa série, uma categoria econômica tem o potencial de anular o "lado mau" de outra de modo que todo o sistema econômico se apresenta como um sistema de contradições que se anulam umas às outras. Para Marx, a sucessão das categorias que se apresentam como antídotos umas das outras nada mais é que a expressão da dogmática divisão entre polos fixos: o bom e o mau. Resulta disso que a solução para as contradições sociais é a supressão do lado mau e a manutenção do lado bom de cada categoria econômica.

Na quinta observação, Marx denuncia que, ao apresentar o movimento da constituição das categorias econômicas como uma espécie de andaimes erguidos com as ideias, os princípios predominantes em cada época, há uma reviravolta no pensamento de Proudhon. Agora, ele abandona a metafísica e volta-se para o encadeamento histórico. Para Marx, o procedimento de opor o bem ao mal e uma categoria como antídoto da outra faz com que a metafísica não funcione mais. "A dialética não é mais o movimento da razão absoluta. Não há mais dialética, há, no máximo, a moral pura" (MARX, 2009, p. 130). As evoluções econômicas não são mais as evoluções da própria razão, reduziram-se aos aforismos morais.

Mas há ainda outra questão nesta quinta observação: para Proudhon, não é a história que rege os princípios, ou seja, não são as condições de vida e produção de cada época que determinam seus princípios importantes, mas, ao contrário, são os princípios

\begin{tabular}{|l|l|l|l|l|}
\hline Govista Dialectus & Ano 3 & n. 8 & Janeiro - Agosto 2016 & p. 77-93 \\
\hline
\end{tabular}


que regem a história. Marx demonstra que o problema aqui é que, se se questiona porque tal ou qual princípio se manifesta em um momento da história e não em outro, obriga-se a aprofundar o entendimento das condições materiais daquele momento da história, das suas forças produtivas e, portanto, é preciso saber quem são os indivíduos daquele momento:

\begin{abstract}
Quando, em seguida, tanto para salvar os princípios quanto a história, indaga-se por que tal princípio se manifestou nos séculos 11 ou 18 e não em outros, é-se obrigatoriamente forçado a examinar com minúcia quais eram os homens dos séculos 11 ou 18, quais eram as suas respectivas necessidades, suas forças produtivas, seu modo de produção, as matérias primas de sua produção - enfim, quais eram as relações entre os homens que resultava de todas essas condições de existência" (MARX, 2009, p. 131).
\end{abstract}

Ao se deparar com o problema de saber porque uma categoria ou princípio se apresenta em uma ou outra época, faz-se necessário que a história saia da dimensão da razão e pouse seus pés na terra firme. É a história (produto da produção dos indivíduos, de suas contradições, de suas lutas) que determina as ideias, não o contrário. A história tem um conteúdo imanente que pode ser entendido pela razão. Não é a ideia que determina a imanência da história. Para entender as ideias, não se deve partir das próprias ideias, mas das condições materiais e objetivas, historicamente construídas, nas quais as ideias se manifestam.

$\mathrm{Na}$ sexta observação, Marx demonstra a inconsistência da concepção proudhoniana das relações econômicas consideradas como leis imutáveis e princípios eternos. Os elementos do método marxiano são aqui explicitados na crítica à concepção de imobilidade histórica. Ao assimilar as ideias de perenidade das relações econômicas provenientes dos economistas ingleses, Proudhon paralisa a história, aniquilando o movimento dialético e inviabilizando o próprio movimento da razão, tornando-o um mero desejo pessoal. Nas palavras de Marx:

Tamanha é a força produtora das contradições que funcionam e que fazem funcionar o sr. Proudhon que, pretendendo explicar o aparecimento sucessivo das relações sociais, ele nega que qualquer coisa possa acontecer, que, pretendendo explicar a produção com todas as suas fases, ele contesta que qualquer coisa possa produzir-se (MARX, 2009, p. 132). 
Tendo sido dadas a priori, as leis que regem as relações econômicas são imutáveis, restando à razão descobri-las tão somente e nunca transformá-las. O sentido mais amplo das leis que regem as relações econômicas é atingir o "bem supremo" que, para Proudhon, seria a igualdade. Se todas as categorias esgrimem-se umas com as outras procurando uma servir como antídoto do lado mau da outra, a finalidade última dessa contenda é a igualdade que, para Proudhon, é a função primordial de todas as categorias econômicas e que, por algum motivo, dela se afastaram.

Marx questiona o porquê de ser a igualdade a hipótese do "bem supremo" a que se destina o resguardo do lado bom das relações econômicas, e não outra hipótese qualquer, chegando à seguinte conclusão: "Ele [Proudhon] imagina que a divisão do trabalho, o crédito, a fábrica, todas as relações econômicas foram inventadas apenas em proveito da igualdade e, no entanto, sempre acabaram se voltando contra ela" (MARX, 2009, p. 135). Assim, para Proudhon, o lado bom de uma relação econômica é aquele que afirma a igualdade e o lado mau aquele que a nega. Seria uma intenção primitiva, um objetivo da Providência, que as contradições cessassem pela aniquilação do lado mau das relações sociais.

Recorrer à Providência como orquestradora da igualdade é o ato final de afirmação da imutabilidade, perenidade e naturalidade das relações sociais instituídas. Isso porque os acontecimentos históricos passam a ser analisados a partir de um objetivo que existia antes de acontecerem. No exemplo da Marx, o objetivo preexistente da Providência na instituição da propriedade fundiária foi expulsar os indivíduos de suas terras e substituí-los por ovelhas, a fim de alimentar a indústria têxtil (Cf. MARX, 2009, pp. 135-6). As condições objetivas, os indivíduos reais que produzem e constroem a história a partir da concretude material já existente, são elementos que Proudhon só considera a partir da intervenção da Providência, ou seja, de Deus.

Fica assim denunciada, por Marx, uma perspectiva conformista das relações econômicas, posto que não há qualquer possibilidade, a se confiar em Proudhon, de que possam ser transformadas. No máximo, contando com a intervenção da Providência, elimina-se o lado mau de algumas categorias econômicas. A perspectiva reformista é pontual, fragmentária e incapaz de questionar a totalidade das relações econômicas.

O objeto da sétima observação é a naturalização das relações sociais burguesas. Marx aponta que o procedimento da economia política clássica é a de classificar as instituições em dois grupos: as naturais e as artificiais: "Dizendo que as relações atuais

\begin{tabular}{|l|l|l|l|l|}
\hline Q Ponista Dialectus & Ano 3 & n. 8 & Janeiro - Agosto 2016 & p. 77-93 \\
\hline
\end{tabular}


- as relações da produção burguesa - são naturais, os economistas dão a entender que é nessas relações que a riqueza se cria e as forças produtivas se desenvolvem segundo as leis da natureza" (MARX, 2009, p. 137). Segundo essa ideia, a história termina quando tais relações de produção se instituem, porque são apresentadas como as únicas capazes efetivar a igualdade, não havendo qualquer alternativa.

A perspectiva proudhoniana naturaliza a base histórica sobre a qual se institui a sociedade burguesa quando polariza os lados bom e mal, apontando para a neutralização do lado mal de uma determinada situação operada pelo lado bom de outra. Há um sistema de compensações que procura anular, conceitualmente, as contradições, apresentando-as como problema a ser superado e não como a própria essência do capitalismo. Nesse movimento, também a desigualdade, o desemprego, a violência, o aprofundamento do abismo entre os mais ricos e os mais pobres, tornam-se situações naturalizadas, a serem anuladas pelo lado bom do capitalismo.

Marx denuncia a imobilidade histórica como elemento conservador na perspectiva reformista de Proudhon. A burguesia só se desenvolve e prospera nos elementos constitutivos da contradição da feudalidade, efetivando-se como o lado mau da feudalidade.

Quando a burguesia se impôs, não se colocou a questão do lado bom e do lado mau da feudalidade. Ela incorporou a forças produtivas que desenvolvera sob a feudalidade. Foram destruídas todas as antigas formas econômicas, as relações civis que lhes correspondiam, o estado político que era a expressão oficial da antiga sociedade civil. (MARX, 2009, p. 138).

O modo de produção feudal é fundado sobre bases antagônicas. A riqueza produzida resultou do desenvolvimento das forças produtivas que, ao ser apropriada por uma classe em detrimento de outra, resulta, ao mesmo tempo, no antagonismo entre classes. Marx procura mostrar que tanto no feudalismo quanto no capitalismo, o antagonismo de classe constitui o próprio movimento histórico. A classe burguesa, inconveniente aos senhores feudais, tornou-se transformadora da sociedade. Entanto, a transformação operada não toca as fundações da produção feudal, mas somente seu aspecto político. A propriedade privada dos meios de produção permanece intocada, efetivando-se uma mudança política no comando da sociedade.

\begin{tabular}{|l|l|l|l|l|}
\hline Q Povista Dialectus & Ano 3 & n. 8 & Janeiro - Agosto 2016 & p. 77-93 \\
\hline
\end{tabular}




\section{O lado mau da sociedade é o motor da história}

Em que resulta a abordagem proudhoniana e porque a crítica elaborada por Marx permanece atual?

A abordagem proudhoniana resulta, como o próprio autor francês reforça (Cf. PROUDHON, 2003, p. 403-4), em que as leis econômicas, naturais e eternas, não podem ser sublevadas; que as greves e organização dos trabalhadores promovem perturbações na harmonia social; que o movimento dos trabalhadores por melhores salários acarreta escassez e que a organização política dos trabalhadores provoca violência contra o monopólio e isso a sociedade não pode permitir.

Para Proudhon, a imobilidade política dos trabalhadores contribui com o desenvolvimento saudável da sociedade em direção à igualdade, pois este é o desígnio da Providência (Cf. PROUDHON, 2003, p. 404). O lado mau, ou, as coalizões de trabalhadores, sua organização política e sua reivindicação por melhores salários obriga a sociedade a medidas amargas, porém necessárias, exercendo sua autoridade e violência a fim de restabelecer a ordem. Nas palavras de Proudhon:

Que cada operário individualmente tenha a livre disposição de sua pessoa e de seus braços, isto pode ser tolerado, mas que os operários empreendam, por meio de coalizões, fazer violência ao monopólio, isto a sociedade não permite. Esmagai o monopólio e abolireis a concorrência, desorganizareis a oficina e semeareis a dissolução por toda a parte. A autoridade, fuzilando os mineiros, encontrou-se como Brutus, colocada entre o amor de pai e os deveres de cônsul: era preciso perder os seus filhos ou salvar a República. A alternativa era horrível, que seja, mas tal é o espírito e a letra do pacto social, tal é o teor da constituição, tal é o desígnio da Providência (PROUDHON, 2003, p. 403-4).

Marx não concorda com as assertivas de Proudhon. Para o filósofo alemão, a organização dos trabalhadores em coalizões, sindicatos e a deflagração de greves é o movimento necessário do antagonismo presente na sociedade burguesa ou, como diria o próprio Proudhon, é o seu lado mau. Em uma sociedade de classes, aquela que detém a hegemonia pretende que a classe explorada permaneça como classe explorada e inerte politicamente. Para tanto, lança mão da violência, quando considera conveniente, como uma solução "amarga", mas necessária.

\begin{tabular}{|l|l|l|l|l|}
\hline Qovista Dialectus & Ano 3 & n. 8 & Janeiro - Agosto 2016 & p. 77-93 \\
\hline
\end{tabular}


A expressão desse movimento histórico, que foge a Proudhon, é o fato empiricamente verificável de que, nas condições atuais da sociedade, a classe trabalhadora se constituiu como o lado mau. É a luta da classe trabalhadora contra o peso insuportável da exploração pelo capital que fornece aos teóricos dessa classe os fundamentos materiais para se pensar e lutar pela emancipação humana, fundamentos que não estão restritos ao pensamento meramente, mas enraízam-se na própria realidade. "A partir dessa observação, a ciência produzida pelo movimento histórico, e que se vincula a ela com pleno conhecimento de causa, deixa de ser doutrinária e se torna revolucionária" (MARX, 2009, p. 142).

$\mathrm{Na}$ verdade, o movimento histórico é produzido exatamente pelo "lado mau". Foi o lado mau do feudalismo (servidão, privilégios, anarquia) que criou os elementos constitutivos para o desenvolvimento da burguesia. Caso esse lado inconveniente, "mau", da sociedade feudal fosse sufocado pelo imobilismo preconizado por Proudhon, o capitalismo jamais teria existido. Caso resultasse verdadeira a concepção de que o lado bom de uma categoria anula o lado mau de outra, então não haveria movimento histórico e a sociedade ainda esgrimiria categorias feudais.

Nesse movimento histórico, a burguesia se colocou como classe revolucionária, e não o fez de modo pacífico, mas em revoluções que destituíram os privilégios "de sangue" da aristocracia feudal e, depois, incorporaram os lados bons e maus do feudalismo. Sem o inconveniente movimento de antagonismo, desenvolvido pelo próprio desenrolar das formações sociais, mudanças históricas seriam impossíveis. Proudhon, no entanto, é a voz que expressa o fato histórico de que, a partir do momento em que se aniquila as formas tradicionais das forças produtivas, a classe revolucionária se torna conservadora (Cf. MARX, 2009, p. 138).

Marx apresenta uma tese diversa daquela de Proudhon: a de que o movimento histórico não cessa precisamente porque o "lado mau" permanece como elemento antagônico, contraditório e, mesmo antes de ser reconhecido, avaliado e proclamado, manifesta-se com os episódios subversivos. Quando deixa de ser classe revolucionária, a burguesia encaminha a reorganização da sociedade nos moldes capitalistas, porém, encaminha também o "lado mau" do capitalismo. Nas palavras de Marx:

Dia após dia, torna-se assim mais claro que as relações de produção nas quais a burguesia se move não têm um caráter uno, simples, mas um caráter dúplice; que, nas mesmas relações em que se produz a

\begin{tabular}{|l|l|l|l|l|}
\hline Q Rovista Dialectus & Ano 3 & n. 8 & Janeiro - Agosto 2016 & p. 77-93 \\
\hline
\end{tabular}


riqueza, também se produz a miséria, que, nas mesmas relações em que há desenvolvimento das forças produtivas, há uma força produtora de repressão; que essas relações só produzem a riqueza burguesa, ou seja: a riqueza da classe burguesa, destruindo continuamente um proletariado sempre crescente (MARX, 2009, p. 139).

Parece clara aqui a impossibilidade de isolar os lados bom e mau. O caráter dúplice da sociedade burguesa não é a existência de polos fixos e imóveis, mas a existência de um duplo caráter das relações sociais impossível de ser fragmentado. Ignorar que o "lado mau" é produzido simultaneamente com o "lado bom" e vice-versa é desconsiderar o movimento histórico. Dessa ideia de imobilidade e eliminação do "lado mau", inclusive, se apropriam os defensores do "fim da história" e da perenização e naturalização da sociedade burguesa.

Trata-se, é evidente, de uma realidade idealizada. Imaginar as relações burguesas sem o antagonismo e a contradição que lhe são imanentes é abstrair as contradições reais na teoria. O movimento grevista, a mobilização dos trabalhadores e a luta por melhores salários são o lado mau da sociedade representado pelos trabalhadores. Esse antagonismo da harmonia social deve, para Proudhon, ser eliminado. Mas é o lado mau que põe a história em movimento. É no movimento de organização em torno de interesses universais que a classe trabalhadora se constitui como classe para si. Seus interesses, sendo ao mesmo tempo universais e de classe, colocam-se em oposição à burguesia. A luta de classes é política. "Não se diga que o movimento social exclui o movimento político. Não há, jamais, um movimento político que não seja, ao mesmo tempo, social" (MARX, 2009, p. 192).

A imobilidade política preconizada por Proudhon reflete o movimento de naturalização das relações sociais burguesas. O silenciar das oposições torna-se o rito sumário da perenização e da conservação da ordem social. Mas a oposição é representada pela classe que produz, pela classe sem a qual a própria sociedade não é viável. Eis a contradição que Proudhon não é capaz de superar. A eliminação do lado mau da sociedade capitalista significa a eliminação da própria classe trabalhadora, algo impossível de ser encaminhado, a não ser como emancipação humana.

A libertação da classe oprimida implica, pois, necessariamente, a criação de uma sociedade nova. Para que a classe oprimida possa libertar-se, é preciso que os poderes produtivos já adquiridos e as relações sociais existentes não possam mais existir uns ao lado de outras. De todos os instrumentos de produção, o maior poder

\begin{tabular}{|l|l|l|l|l|}
\hline Q Ponista Dialectus & Ano 3 & n. 8 & Janeiro - Agosto 2016 & p. 77-93 \\
\hline
\end{tabular}


produtivo é a classe revolucionária mesma. A organização dos elementos revolucionários como classe supõe a existência de todas as forças produtivas que poderiam se engendrar no seio da sociedade antiga. (MARX, 2009, p. 191).

No "corpo social" todas as relações coexistem simultaneamente, de modo que não é possível retirar aquilo que se considera como "mal" preservando o que se considera "bom", a realidade não é compartimentada, nem serial e nem pode ser subdividida, a não ser conceitualmente, de maneira abstrata. A imanência do real tem sua própria lógica e estrutura, que pode sim ser descoberta e entendida pela razão, mas não pode ser retirada do todo.

Marx demonstra, no texto aqui analisado, que perscrutar a imanência do real não é fazer a oposição fixa entre os polos que se colocam em contradição, mas entender a necessidade da constituição e da reconstituição crítica do movimento do real. Este é o elemento do método marxiano que se efetiva como tarefa do pesquisador: desnudar, descobrir, criticar e expor o real, que não se mostra pacificamente. Neste sentido, a razão é absolutamente necessária, mas somente como razão que está em relação com o real, que se constitui a partir do real e não como razão apartada, centrada nela mesma.

\section{Considerações Finais}

A Miséria da Filosofia encaminha importantes elementos do método marxiano que apontam para um modo de entendimento do real que foge completamente àquele que concebe as instâncias e instituições da sociedade burguesa como coisas atemporais, naturais e independentes do movimento histórico. Na verdade, é o exato oposto que ganha importância nas linhas críticas de Marx. A realidade deve ser objeto de profunda análise, caso contrário, pode-se incorrer nos dois erros de Proudhon, quais sejam: tomar a parte pelo todo e confundir a aparência com a essência. Já se falou do primeiro erro quando da descrição dos sete aspectos abordados por Marx a respeito do livro de Proudhon. Sobre o segundo erro, convém fazer alguns comentários finais, pois se trata de elemento constitutivo e indispensável à apreensão do método marxiano.

Em $O$ Capital, Marx diz que se a aparência se confundisse com a essência, então toda ciência seria desnecessária (MARX, 2013a), entretanto, embora não se confundam, aparência e essência estão interligadas, apresentam-se simultaneamente, não podem ser dissociadas, a não ser pela análise crítica, radical, do fenômeno. Por não se confundir

\begin{tabular}{|l|l|l|l|l|}
\hline Qenista Dialectus & Ano 3 & n. 8 & Janeiro - Agosto 2016 & p. 77-93 \\
\hline
\end{tabular}


com a essência mesmo sendo simultânea a ela, a aparência pode ser enganosa (e o é na maior parte das vezes), mascarando a realidade de modo que não pode ser tomada como parâmetro, sob o risco de levar a enganosos julgamentos e errôneas análises.

Em 1846-7 esse entendimento já se faz presente quando o filósofo alemão demonstra a percepção fenomênica de Proudhon em relação ao movimento histórico, expressa em uma carta a Annenkov:

O Sr. Proudhon confunde as ideias e as coisas. Os homens jamais renunciam àquilo que conquistaram, mas isso não quer dizer que não renunciem jamais à forma social sob a qual adquiriram determinadas forças produtivas. Muito ao contrário. Para não se verem privados do resultado obtido, para não perder os frutos da civilização, os homens são constrangidos, a partir do momento em que o modo do seu comércio já não corresponde às forças produtivas adquiridas, a modificar todas as suas formas sociais tradicionais (MARX, 2009, p. 246-7).

$\mathrm{Na}$ crítica devastadora da confusão entre "ideias" e "coisas", fica marcada a trilha que leva ao erro de se confundir aparência e essência. A constatação desse erro tem importância central para a análise da sociedade capitalista, para as reflexões sobre sua superação e para a efetivação das transformações profundas que levam à emancipação humana. Marx já havia abordado essa questão em Crítica da Filosofia do Direito de Hegel - Introdução: “As revoluções precisam de um elemento passivo, de uma base material. A teoria só é efetivada num povo na medida em que é a efetivação de suas necessidades. [...] Não basta que o pensamento procure se realizar; a realidade deve compelir a si mesma em direção ao pensamento”. (MARX, 2010, p. 152).

A teoria deve ser materializada e isso só é possível quando se apresenta como expressão dos anseios e demandas que se originam na vida real das pessoas reais. As demandas e necessidades reais são aquelas que se expressam na classe social cuja função histórica é a emancipação humana: a classe trabalhadora. Não pode haver confusão entre aquilo que é a essência do capital e aquilo que é o interesse real da classe trabalhadora: a emancipação humana.

Neste sentido, a classe trabalhadora é o lado mau da sociedade burguesa, porque é dela a função de pôr a história em movimento. Os socialistas e os comunistas são os teóricos dessa classe. Contudo, para Marx, enquanto as condições materiais não estiverem suficientemente desenvolvidas, "esses teóricos são apenas utopistas que, para

\begin{tabular}{|l|l|l|l|l|}
\hline Rovista Dialectus & Ano 3 & n. 8 & Janeiro - Agosto 2016 & p. 77-93 \\
\hline
\end{tabular}


amenizar os sofrimentos das classes oprimidas, improvisam sistemas e correm atrás de uma ciência regeneradora" (2009, p. 141).

As questões relativas ao método marxiano presentes no embate entre Marx e Proudhon revelam-se significativos e atuais nesse momento de recrudescimento de uma perspectiva conservadora e naturalizadora da ordem social burguesa. O movimento de eliminação do "lado mau" do capital inclui a concatenação política de limitação das possibilidades de mobilização da classe trabalhadora. Em nome da estabilidade sócio econômica, ou de uma paz fictícia, a violenta repressão dos trabalhadores resulta em uma organização societária em constante tensão.

A defesa da noção de fim da história, presente em Proudhon e presente em nossos dias, esconde, elude e descaracteriza o antagonismo entre capital e trabalho. Marx entende que, embora a perspectiva proudhoniana procure eliminar o "lado mau", destruindo os antagonismos em favor de uma humanização do capital, as condições objetivas impõem as contradições sociais, sendo impossível eliminá-las. Não se trata de se opor ao ideal de igualdade preconizado por Proudhon, mas de ter a clareza de que essa igualdade só é possível a partir da superação da sociedade capitalista, viável apenas quando o "lado mau" da sociedade põe a história em movimento.

\section{Referências}

MARX, Karl e ENGELS, Friedrich. A sagrada família ou A crítica da crítica crítica contra Bruno Bauer e consortes. São Paulo: Boitempo, 2009.

MARX, Karl. Miséria da filosofia: resposta à Filosofia da miséria, do Sr. Proudhon. São Paulo: Expressão Popular, 2009a.

MARX, Karl. Carta de Marx a P. V. Annenkov. IN: MARX, Karl. Miséria da filosofia: resposta à Filosofia da miséria, do Sr. Proudhon. São Paulo: Expressão Popular, 2009a. pp, 243-257.

MARX, Karl. Manuscritos econômico-filosóficos. São Paulo: Boitempo; 2009b.

MARX, Karl. Crítica da filosofia do direito de Hegel - Introdução. In: Marx, Karl. Crítica da filosofia do direito de Hegel. São Paulo: Boitempo; 2010, pp. 145-157.

MARX, Karl e ENGELS, Friedrich. A ideologia alemã: São Paulo: Boitempo, 2013.

MARX, Karl. O capital: São Paulo: Boitempo, 2013a.

MOREL, José Carlos Orsi. Introdução. IN: PROUDHON, Pierre-Joseph. Sistema das contradições econômicas ou filosofia da miséria. São Paulo: Editora Ícone, 2003, pp. 7-32.

\begin{tabular}{|l|l|l|l|l|}
\hline Qovista Dialectus & Ano 3 & n. 8 & Janeiro - Agosto 2016 & p. 77-93 \\
\hline
\end{tabular}


NETTO, José Paulo. Introdução. IN: MARX, Karl. Miséria da filosofia: resposta à Filosofia da miséria, do Sr. Proudhon. São Paulo: Expressão Popular, 2009a. pp. 1133.

PROUDHON, Pierre-Joseph. Sistema das contradições econômicas ou Filosofia da miséria. São Paulo: Editora Ícone, 2003.

\begin{tabular}{|l|l|l|l|l|}
\hline Qevista Dialectus & Ano 3 & n. 8 & Janeiro - Agosto 2016 & p. 77-93 \\
\hline
\end{tabular}

